\title{
PENENTUAN RUTE KUNJUNGAN COLLECTOR ANGSURAN PINJAMAN MENGGUNAKAN METODE ALGORITMA SWEEP DI AREA KECAMATAN MENGANTI
}

\author{
Linggar Probo Prastiyo \\ e-mail : linggarlinggar42@gmail.com \\ Teknik Industri, Fakultas Teknik \\ Universitas Maarif Hasyim Latif, Sidoarjo, Indonesia
}

\begin{abstract}
ABSTRAK
Penelitian ini membahas tentang aplikasi Algoritma Sweep untuk membuat rute penagihan yang terbaik. Algoritma Sweep adalah Algoritma dari dua kelompok, yaitu kelompok pertama yang terdiri dari pengelompokan antar titik dan yang kedua mengatur rute untuk setiap kelompok. Penelitian ini menggunakan metode titik terdekat. Langkah metode ini adalah memasukkan satu per satu alamat konsumen dari jarak terdekat. Langkah ini diulang sampai setiap alamat konsumen dikunjungi. Dari perhitungan yang telah dilakukan menggunakan Algoritma Sweep, total jarak 39,45 km diperoleh dengan penghematan jarak tempuh meningkat $17,85 \mathrm{~km}$ jauh lebih kecil dari total jarak awal $57,3 \mathrm{~km}$. Ini menunjukkan bahwa Algoritma Sweep dapat digunakan untuk mendapatkan solusi untuk meningkatkan rute penagihan terbaik guna meningkatkan kinerja para field collector angsuran pinjaman kredit di kecamatan Menganti.
\end{abstract}

Kata kunci: penentuan rute kunjungan, Algoritma Sweep

\section{ABSTRACT}

This research discusses the application of the Sweep Algorithm to create the best billing route. The Sweep algorithm is an algorithm of two groups. The first group consists of grouping between points, and the second sets the route for each group. This study used the method of nearby points. The step of this method is to enter one by one the addresses of consumers from the closest distance. This step is repeated until each consumer address is visited. From the calculations that have been carried out using the Sweep Algorithm, a total distance of $39.45 \mathrm{~km}$ was obtained with an increased mileage saving of $17.85 \mathrm{~km}$, much smaller than the total initial distance of $57.3 \mathrm{~km}$. It shows that the Sweep Algorithm could improve the best collection routes to improve the performance of field collectors of credit loan installments in Menganti sub-district.

Keywords: determination of visit route, Sweep Algorithm

\section{PENDAHULUAN}

Dalam menangani kredit macet perusahaan mengambil tindakan dengan langkah kebijaksanaan antara lain, melakukan kegiatan penagihan dana angsuran kredit tersebut. Hal ini bisa di jalankan oleh collector yang bertugas di area tagihnya masing-masing untuk menangani kredit yang pembiayaannya lewat dari jangka waktu yang ditetapkan sebelumnya. Adanya penagihan yang dilakukan, setiap collector di nyatakan dalam alur kerja yang mencakup pembuatan perjanjian sampai dengan penagihan kepada konsumen yang dilakukan setiap hari oleh collector perusahaan PT.X Cabang Menganti. Bertambahnya konsumen bermasalah (kredit macet) di perusahaan PT.X Cabang Menganti, maka munculah permasalahan pada kinerja collector hingga tidak tercapainya target yang sudah ditentukan perusahaan kepada collector. Selain itu, karena jumlah collector terbatas, collector sering kali mengeluh karna banyaknya konsumen yang harus ditagih dan penentuan rute kunjung yang kurang terkoordinir dengan baik sehingga sering terjadi konsumen yang tidak tertagih secara maksimal.

Untuk mendukung kinerja para collector di perusahaan PT.X Cabang Menganti, maka dibutuhkan penentuan rute jalur penagihan terbaik untuk memaksimalkan waktu kunjung dan untuk mengurangi manipulasi waktu dari collector tersebut. Oleh karena itu permasalahaan ini perlu di analisa ulang untuk memperoleh rute terbaik dan tercepat dalam meningkatkan kinerja collector. Sehingga kegiatan penagihan dapat dilakukan dengan baik dan suatu sistem informasi penagihan untuk mengelola proses penagihan sekaligus mengolah data menjadi informasi yang dibutuhkan perusahaan.

\section{METODE PENELITIAN}

Proses identifikasi dilakukan menggunakan cara menganalisis dan mengamati hal-hal yang berkaitan pada proses perjalanan yang berlangsung di perusahaan secara detail, seperti data perhitungan jarak dari 
perusahaan ke konsumen, lintasan penagihan dan yang terkait lainnya. Sehingga dapat di identifikasi permasalahan yang berhubungan dengan penentuan rute penagihan diperusahaan PT.X Cabang Menganti dengan tujuan yang dicapai adalah meminimalkan jarak pada lintasan yang dilalui (rute) dan memaksimalkan kinerja para collector bedasarkan pengambilan rute yang lebih terbaik.

Dalam Metode Sweep terdapat dua tahap, yaitu tahap clustering dan tahap pembentuan rute untuk masing-masing cluster (Anshori \& Fudhla, 2017; Dondo \& Cerdá, 2013). Sedangkan menurut (Fontaine et al., 2020) metode Algoritma Sweep adalah sebuah metode yang menghasilkan solusi alternatif yang mempunyai nilai obyektif yang sama serta menghasilkan solusi yang sesuai dengan kondisi di lapangan. Adapun langkahlangkah dalam tahap clustering dan pembentukan rute menurut (Blocho, 2020), sebagai berikut:

Tahap pengelompokan:

1. Menentukan posisi alamat dalam koordinat kartesius

2. Menentukan seluruh koordinat polar setiap alamat

3. Pembentukan clustering

4. Menentukan setiap clustering telah dikelompokan

Tahap pembentukan rute:

1. Menentukan langkah inisiasi

2. Memilih titik yang akan dikunjungi

3. Menambah titik selanjutnya untuk dikunjungi Setelah semua titik telah dikunjungi maka menambahkan titik awal perjalanan pada akhir rute.

Permasalahan penentuan rute pada penelitian sebelumnya. Algoritma metode sweep merupakan salah satu algoritma yang bias digunakan untuk memecahkan masalah penentuan rute. Di dalam permasalahan rute, factor biaya atau waktu tempuh biasa menjadi pertimbangan dalam pengambilan keputusan. Berikut jenis-jenis permasalah rute (VRP) yang pernah diteliti:
1. Capacitated VRP (VRP) Faktor : setiap kendaraan mempunyai kapasitas yang terbatas.(Vigo, 1996), (Schönberger, 2015), (Mańdziuk \& Świechowski, 2017), (Gadegaard \& Lysgaard, 2020).

2. VRP With Time Windows (VRPTW) Faktor : pelanggan harus dilayani dengan waktu tertentu. (PAN \& FU, 2013), (Spliet et al., 2018; Spliet \& Gabor, 2015), (Dalmeijer \& Desaulniers, 2020).

3. Multiple Depot VRP (MDVRP) Faktor : distributor memiliki banyak depot. (Sundar et al., 2016), (Kunnapapdeelert \& Kachitvichyanukul, 2018).

4. VRP With Pick-Up and Delivering (VRPPD) Faktor : pelanggan diperbolehkan mengembalikan barang ke depot asal. (Kristanto et al., 2018), (Yang et al., 2018), (Liu et al., 2019).

5. Split Delivery VRP (SDVRP) Faktor : pelanggan dilayani dengan kendaraan berbeda.(Chen et al., 2017), (Fábry, 2019)

6. Stochastic VRP (SVRP) Faktor : munculnya random values (seperti jumlah pelanggan, jumlah permintaan, waktu perjalanan atau waktu pelayanan)(Zou \& Dessouky, 2018), (Marinakis, 2015).

7. Periodic VRP Faktor : pengantaran hanya dilakukan di hari tertentu. (Alves et al., 2019), (Kouider et al., 2019).

8. VRP dengan Cross Dock Factor : penjadwalan rute kendaraan dengan kedatangan pickup dan keberangkatan delivery yang berlangsung secar asimultan. (Fudhla et al., 2010), (Agustina, 2016) , (Liao, 2020), (Anshori et al., 2017), (Anshori \& Fudhla, 2017)

\section{HASIL DAN PEMBAHASAN}

Tabel data list konsumen menjelaskan daftar list konsumen perusahaan yang akan di kunjungi oleh collector.

Tabel 1 data list konsumen

\begin{tabular}{|c|c|c|}
\hline NO KONTRAK & NAMA & ALAMAT \\
\hline xxx000682119 & NITA TRI MULYASARI & $\begin{array}{c}\text { PERUM DE NAILA BLOK C 9NO } 3 \text { DRANCANG MENGANTI GRESIK RT OOORW OOO } \\
\text { DS.Drancang KEC.Kec.Menganti Kab.Gresik }\end{array}$ \\
\hline$\times x \times 000847419$ & HERI KARTONO & DS HENDROSARI RT O1 RW 01 KEC MENGANTI KAB GRESIK \\
\hline xxx001174619 & SUPARMAWATI & $\begin{array}{c}\text { PERUM GREEN MENGANTI JL.FLAMBOYAN BLOK D1 NO } 18 \text { RTO29 RW } 009 \\
\text { DS.Drancang KEC.Kec Menganti Kab Gresik }\end{array}$ \\
\hline xxx0009157118 & YANOEARIOES SARENG & PERUM BUKIT CEMARA WANGI B2 NO OS HULAAN MENGANTI GRESIK \\
\hline xx×000790718 & TRI WAHYUDIONO & DS GEMPOL KURUNG RT 01 RW 02 GEMPOL KURUNG MENGANTI GRESIK \\
\hline xxx000985718 & SAMSUL ARIF & PELEMWATU RT 05 RW 03 PELEMWATU MENGANTI GRESIK \\
\hline$x \times \times 000053119$ & ADEK ARIFIANSYAH & RANDU PADANGAN RT 21 RW 07 Randu padangan Kec.Menganti Kab Gresik \\
\hline xxx001136018 & KUSNAN & BONGSO WETAN NO 50 RT 021 RW 006 PENGALANGAN MENGANTI GRESIK \\
\hline xxx000541418 & SUMARLIYAH & BONGSO WETAN NO 50 RT 021 RW OOG PENGALANGAN MENGANTI GRESIK \\
\hline$x \times \times 000630618$ & AHMAD ROHID & PENGAMPON RTO14 RWOO7 SETRO KEC.MENGANTI KAB.GRESIK \\
\hline$x \times 001081618$ & AMINATUN & DSN WONOKOYO RT 28 RW O9 KEC.MENGANTI KAB.GRESIK \\
\hline xxx000012418 & MUHAMMAD ADENAN & DS HULAAN RT 14 RW 07 KEC.MENGANTI KAB.GRESIK \\
\hline xxx001208818 & ESWANDI & DSN GELINTUNG RT 1 RW O4 DS KEPATIHAN KEC MENGANTI KAB GRESIK \\
\hline$x \times \times 000424119$ & RUBIYATI & DS KEPATIHAN RT O1 RW 10 KEC MENGANTI KAB GRESIK \\
\hline xxx000093619 & RANI ANGGRAINI & DSN KUTIL RT 25 RT 05 DS GEMPOL KURUNG KEC MENGANTI KAB GRESIK \\
\hline
\end{tabular}


Tabel 2 kode alamat

\begin{tabular}{|c|c|c|c|}
\hline No & NAMAA & KOOF & ALAMAT \\
\hline o & PT X CA BANG MENGANTI & AO & M.NGASINAN BEHOWO KaC, RAKAL Kab, GRESIK \\
\hline 1 & NTA TUI MULYYASAMI & A 1 & 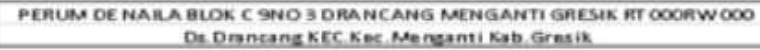 \\
\hline $\mathbf{z}$ & Heni Kantono & $A z$ & 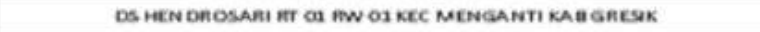 \\
\hline $\mathbf{3}$ & SUPARMA WATI & Aa & 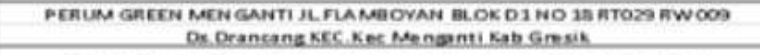 \\
\hline 4 & VANOEARIOES SARENG & A4 & PERUM BUKIT CEMARA WANGI B2 NOOS HULAAN MENGANTI GRESIK \\
\hline s & ThI WAMUUDiono & As & DS GEMP OL KUHUN G RT OL FWO2 GEMPOL.KUHUNG MENGANT GRESUK \\
\hline 6 & Samesurame & A6 & PEUKMWATU HT CS RW O3 PELEMNATU MENGANTI GRESIK \\
\hline 7 & ADEK ARIFANSYAH & A9 & 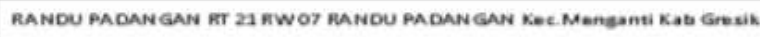 \\
\hline $\mathbf{s}$ & RUSHAN & $A>$ & BONGSO WETAN WO SO NT O23 HW OOE PENGALANGAN MENGANTI GRESIK \\
\hline 9 & SURAARUVAH & An & BONGSO WETAN WO SO HT OZI HW OOE PENGALANGAN MENGANTI GHESIK \\
\hline 10 & AнМАอ ПОМВ & A.10 & RENGAMPON MO3d "WWOOZ SETRO KEC MENGANTI KA G GRESIK \\
\hline 12 & AMANATUN & An & DSN WONOKONO RT 2S RW OS KEC MENGANT KAR GRESIK \\
\hline 12 & MUHAMMMAO ADERAN & A12 & 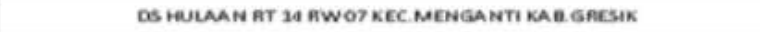 \\
\hline 13 & ESWANoi & A13 & DSN GEUNTUNG RT a HWOA DS KEPATHHAN KEC MENGANTI KAI GHESIK \\
\hline 14 & nuarvati & a14 & DS KEPATIHAN FT OA RW 30 KEC MENGANTI KAR GRESIK \\
\hline 1s & MANI ANGGRAINI & Aas & 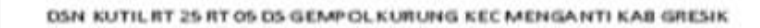 \\
\hline
\end{tabular}

Tabel di atas adalah list konsumen yang sudah di pasang kode untuk menandai titik yang akan di kunjungi oleh collector.

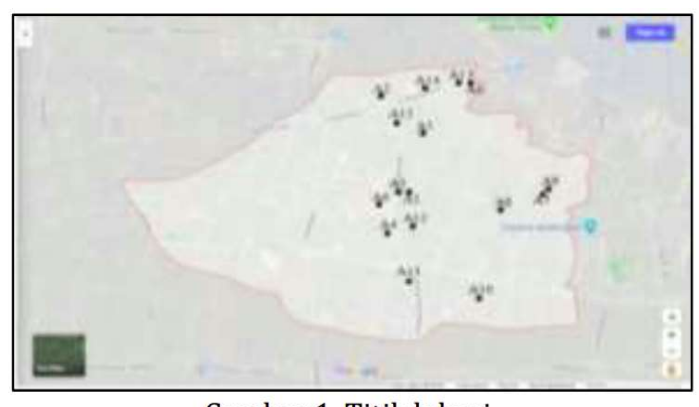

Gambar 1. Titik lokasi

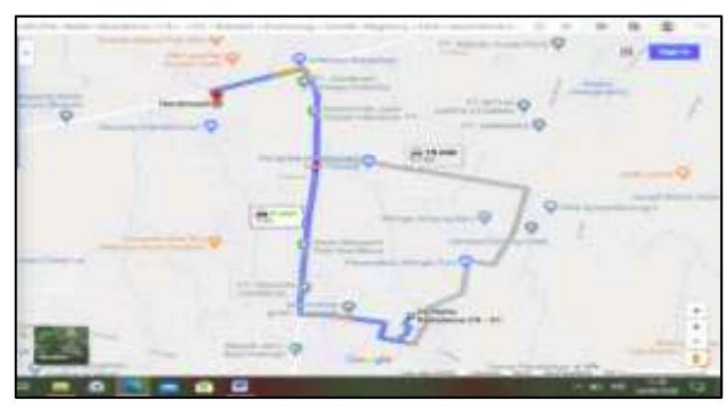

Gambar 2. Rute jarak

Gambar di atas menjelaskan cara melihat Jarak antar titik dengan bantuan google maps. Tabel di bawah adalah matrik jarak antar titik.

Gambar di atas menjelaskan titik antar konsumen dengan bantuan google maps.

Tabel 3 Matrix jarak

\begin{tabular}{|c|c|c|c|c|c|c|c|c|c|c|c|c|c|c|c|c|}
\hline 0 & A0 & A1 & A2 & A3 & A4 & A5 & A6 & A7 & A8 & A9 & A10 & A11 & A12 & A13 & A14 & A15 \\
\hline A0 & 0 & 5,8 & 2,9 & 4,7 & 7 & 3,4 & 5,2 & 7,5 & 5,6 & 7,5 & 11 & 8,5 & 9 & 1,4 & 1,7 & 3,1 \\
\hline A1 & 5,8 & 0 & 4 & 1,8 & 3,5 & 1,1 & 1,7 & 4,4 & 2,4 & 4,4 & 8,1 & 5 & 3,2 & 4,3 & 4 & 2,6 \\
\hline A2 & 2,9 & 4 & 0 & 4,1 & 5,3 & 4,6 & 3,5 & 7,8 & 5,8 & 7,8 & 9,2 & 3,7 & 5 & 1,6 & 1,2 & 1,4 \\
\hline A3 & 4,7 & 1,8 & 4,1 & 0 & 3,6 & 1,8 & 1,8 & 5 & 3 & 5 & 7,5 & 5,1 & 3,3 & 4,4 & 4 & 2,7 \\
\hline A4 & 7 & 3,5 & 5,3 & 3,6 & 0 & 4,1 & 2 & 6,1 & 4 & 6,1 & 4 & 1,7 & 0,65 & 5,6 & 5,3 & 3,9 \\
\hline A5 & 3,4 & 1,1 & 4,6 & 1,8 & 4,1 & 0 & 2,4 & 3,4 & 1,4 & 3,4 & 5,5 & 6,2 & 3,8 & 4,9 & 4,6 & 3,2 \\
\hline A6 & 5,2 & 1,7 & 3,5 & 1,8 & 2 & 2,4 & 0 & 5,6 & 3,6 & 5,6 & 5,9 & 3,6 & 1,7 & 3,8 & 3,5 & 2,1 \\
\hline A7 & 7,5 & 4,4 & 7,8 & 5 & 6,1 & 3,4 & 5,6 & 0 & 2,2 & 0,2 & 7,4 & 6,6 & 5,5 & 8,1 & 7,8 & 6,4 \\
\hline A8 & 5,6 & 2,4 & 5,8 & 3 & 4 & 1,4 & 3,6 & 2,2 & 0 & 2,2 & 5,3 & 4,5 & 3,3 & 6,1 & 5,8 & 4,4 \\
\hline A9 & 7,5 & 4,4 & 7,8 & 5 & 6,1 & 3,4 & 5,6 & 0,2 & 2,2 & 0 & 7,9 & 6,6 & 5,5 & 8,1 & 7,8 & 6,4 \\
\hline A10 & 11 & 8,1 & 9,2 & 7,5 & 4 & 5,5 & 5,9 & 7,4 & 5,3 & 7,9 & 0 & 3,5 & 4,5 & 9,5 & 9,2 & 7,8 \\
\hline A11 & 8,5 & 5 & 3,7 & 5,1 & 1,7 & 6,2 & 3,6 & 6,6 & 4,5 & 6,6 & 3,5 & 0 & 2,4 & 7,4 & 7 & 5,7 \\
\hline A12 & 9 & 3,2 & 5 & 3,3 & 0,65 & 3,8 & 1,7 & 5,5 & 3,3 & 5,5 & 4,5 & 2,4 & 0 & 5,3 & 4,9 & 3,6 \\
\hline A13 & 1,4 & 4,3 & 1,6 & 4,4 & 5,6 & 4,9 & 3,8 & 8,1 & 6,1 & 8,1 & 9,5 & 7,4 & 5,3 & 0 & 1,7 & 1,7 \\
\hline A14 & 1,7 & 4 & 1,2 & 4 & 5,3 & 4,6 & 3,5 & 7,8 & 5,8 & 7,8 & 9,2 & 7 & 4,9 & 1,7 & 0 & 1,4 \\
\hline A15 & 3,1 & 2,6 & 1,4 & 2,7 & 3,9 & 3,2 & 2,1 & 6,4 & 4,4 & 6,4 & 7,8 & 5,7 & 3,6 & 1,7 & 1,4 & 0 \\
\hline
\end{tabular}




\section{Perhitungan jarak sesuai daftar list}

Berdasarkan gambar 1, lokasi - lokasi yang akan dikunjungi oleh collector ditandai dengan titik A0-A1A2-A3-A4-A5-A6-A9-A7-A8-A10-A11-A12-A13-A14A15-A0. Selanjutnya jarak antar lokasi (dihitung dalam satuan kilo meter), dari ke A0 sampai 1- 15 lokasi konsumen tersebut.

Setelah diketahui lokasi dari masingmasing alamat konsumen maka dilakukan pengolahan data jarak menjadi sebuah matriks jarak dari masing-masing alamat. Matriks jarak ini akan untuk menghitung jarak antar konsumen. Matriks ini didapatkan dari pengolahan data sekunder yang ada di PT. X cabang menganti, dan google map digunakan untuk membantu menentukan jarak dari rute yang dilewati. Dalam menentukan jarak yang digunakan adalah jarak terbaik bukan tercepat.

Karena tujuan dari penelitian ini adalah mencari rute terbaik antar konsumen dengan konsumen lainnya, langkah pertama untuk mencari data jarak adalah melihat alamat dari 2 alamat yang akan dicari jaraknya seperti di gambar 2 pada kunjungan no 1 sesuai daftar list. Nita tri mulyasari dengan heri kartono, alamat nita tri mulyasaria adalah perum de naila blok c 9 no 3 drancang menganti gresik rt 000 rw 000 ds.drancang kec.menganti kab.gresik sedangkan alamat heri kartono adalah ds hendrosari rt 01 rw 01 kec. Menganti kab. Gresik. Kemudian masukan alamat tersebut ke dalam kolom asal dan tujuan. Apabila titik yang diminta tidak tepat, maka harus menggeser penanda titik dengan cara manual.setelah memasukan alamat, akan didapatkan jarak kedua titik.

Berdasarkan gambar 2, jarak yang didapatkan adalah $4 \mathrm{~km}$. Begitu pula cara untuk mengetahui jarak antar konsumen yang lain. Berikutnya semua titik dipilih dan dimasukan kedalam daftar simpan khusus agar memudahkan dan dapat dilihat hanya titik-titik yang kita tandai saja. Dalam penelitian ini penulis memasukan 16 titik. Terdiri dari a0 titik lokasi kantor dan 15 titik a1-a15 alamat konsumen.

Dari gambar 1, lokasi - lokasi yang akan dikunjungi sesuai daftar list, ditandai dengan titik a0-a1a2-a3-a4-a5-a6-a9-a7-a8-a10-a11-a12- a13-a14-a15-a0. Selanjutnya jarak antar lokasi (dihitung dalam satuan kilo meter), dari titik a0 sampai 1 - 16 lokasi konsumen lainnya. Maka dihasilkan total jarak sebagai berikut:
Tabel 4 Total jarak sesuai list

\begin{tabular}{|c|c|c|}
\hline NO & JARAK ANTAR TITIK & TOTAL JARAK \\
\hline 0 & A0-A1 & 5,8 \\
\hline 1 & A1-A2 & 4 \\
\hline 2 & A2-A3 & 4,1 \\
\hline 3 & A3-A4 & 3,6 \\
\hline 4 & A4-A5 & 4,1 \\
\hline 5 & A5-A6 & 2,4 \\
\hline 6 & A6-A9 & 5,6 \\
\hline 7 & A9-A7 & 0,2 \\
\hline 8 & A7-A8 & 2,2 \\
\hline 9 & A9-A10 & 7,9 \\
\hline 10 & A10-A11 & 3,5 \\
\hline 11 & A11-A12 & 2,4 \\
\hline 12 & A12-A13 & 5,3 \\
\hline 13 & A13-A14 & 1,7 \\
\hline 14 & A14-A15 & 1,4 \\
\hline 15 & A15-A0 & 3,1 \\
\hline & TOTAL & 57,3 \\
\hline
\end{tabular}

Dari tabel di atas bisa dlihat perhitungan total jarak dari keseluruhan titik yang berdasarkan list perusahaan. Dima na dari total jarak keseluruhan berjarak 57,3 km.

\section{Metode sweep}

Penerapan metode sweep yakni setelah mengetahui rute awal penagihan selanjutnya pengolahan data menggunakan algoritma sweep untuk perhitungan total jarak yang ditempuh untuk satu kali kunjungan dan berdasarkan data asli dari perusahaan dengan pengelompokan sesuai dengan jarak terkecil dari kantor dan dilanjutkan dengan jarak terdekat dengan tujuan pertama dan seterusnya.

\section{CLUSTERING Metode SWEEP}

Tahap pertama dalam Algoritma Sweep adalah mengelompokkan masing-masing titik alamat konsumen ke dalam sebuah cluster. Langkah - langkah tahapan clustering yaitu: Menggambarkan masingmasing alamat dalam koordinat kartesius dan menetapkan lokasi kantor sebagai pusat koordinat.

Dari penjelasan diatas, lalu 16 titik kita implementasikan kedalam kasus. Namun mulamula kita harus memasukan titik dari semua kedalam satu maps guna mencari nilai $\mathrm{x}$ dan $\mathrm{y}$. 


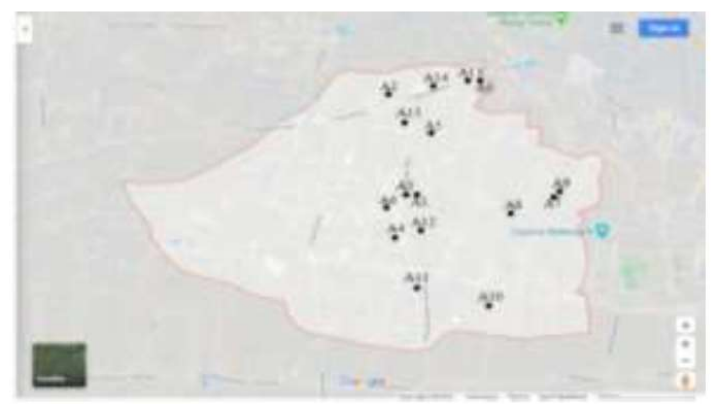

Gambar 3. Titik lokasi

Gambar 3 Berikut adalah gambar titik lokasi yang akan dikunjungi oleh collector dengan bantuan Google Maps.

Menentukan semua koordinat polar dari masing -masing alamat konsumen yang berhubungan. Langkah mengubah koordinat kartesius $(\mathrm{x}, \mathrm{y})$ menjadi koordinat $\operatorname{polar}(\mathrm{r}, \theta)$ adalah sebagai berikut:

$$
\begin{gathered}
r=\sqrt{2}+2 \\
\Theta=\arctan \frac{x}{y}
\end{gathered}
$$

Setelah semua titik masuk kedalam maps, maka dibuat garis lintang dan bujur yang diberi nama garis $\mathrm{x}$ dan garis y dan bertemu di titik $(0,0)$. Titik $(0,0)$ ini diletakan tepat pada kantor dimana sebagai titik 0 untuk penentuan rute untuk awal di tentukan. Bisa kita lihat pada gambar berikut:

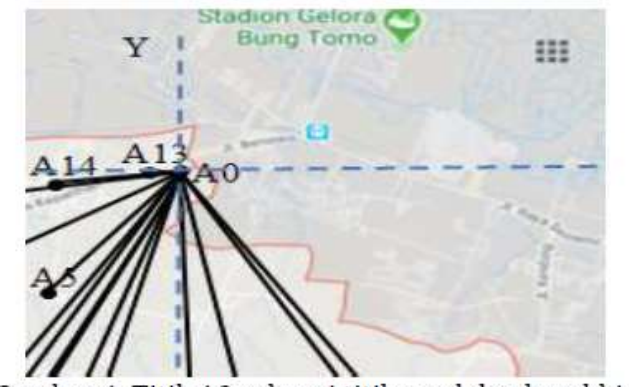

Gambar 4. Titik A0 sebagai titik awal dan berakhir

Pada gambar di atas menjelaskan titik A0 atau lokasi kantor sebagai titik kordinat, dimana titik lokasi tersebut berawal dan berakhirnya perhitungan perjalanan kunjungan collector.

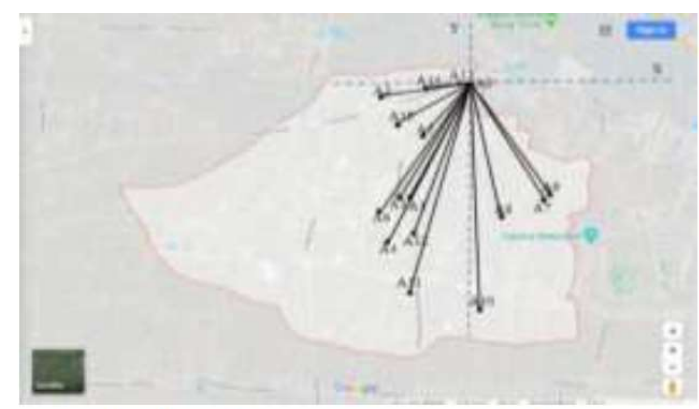

Gambar 5 Rute sesuai metode Sweep
Dari gambar 4.3, lokasi - lokasi yang akan dikunjungi sesuai metode Sweep, ditandai dengan titik A0-A13-A14-A2-A15-A5-A6-A3-A5-A1-A4- A12-A11A10-A8-A7-A9-A0. Selanjutnya jarak antar lokasi (dihitung dalam satuan kilo meter), dari titik A0 sampai 1 - 15 lokasi konsumen. Maka dihasilkan total jarak sebagai berikut:

Tabel 5 Perhitungan jarak sesuai metode

\begin{tabular}{|c|c|c|}
\hline NO & JARAK ANTAR TTIK & TOTAL JARAK \\
\hline 0 & A0-A13 & 1,4 \\
\hline 1 & A13-A14 & 1,7 \\
\hline 2 & $\mathrm{~A} 14-\mathrm{A} 2$ & 1,2 \\
\hline 3 & $\mathrm{~A} 2-\mathrm{A} 15$ & 1,4 \\
\hline 4 & A15-A5 & 3,2 \\
\hline 5 & A5-A6 & 2,4 \\
\hline 6 & $\mathrm{~A} 6-\mathrm{A} 3$ & 1,8 \\
\hline 7 & A5-A1 & 1,1 \\
\hline 8 & A1-A4 & 3,5 \\
\hline 9 & A4-A12 & 0,65 \\
\hline 10 & A12-A11 & 2,4 \\
\hline 11 & A11-A10 & 3,5 \\
\hline 12 & $\mathrm{~A} 10-\mathrm{A} 8$ & 5,3 \\
\hline 13 & A8-A7 & 2,2 \\
\hline 14 & A7-A9 & 0,2 \\
\hline 15 & A9-A0 & 7,5 \\
\hline \multicolumn{2}{|r|}{ TOTAL } & 39,45 \\
\hline
\end{tabular}
Sweep

Dari tabel di atas bisa dlihat perhitungan total jarak dari keseluruhan titik yang dihasilkan dari perhitungan metode Algoritma Sweep. Dimana dari total jarak keseluruhan berjarak 39,45 km.

\section{Analisis Perbandingan}

Dari metode yang telah diperhitungkan sebelumnya. Kemudian pada tahap ini sebagai tahap akhir pemecahan masalah pada perusahan hasil dirangkum menjadi satu. Sebagai langkah mencari alternatif solusi perbandingan sangatlah penting guna membuktikan secara teori bahwa metode yang akan dipakai memberi hasil positif. Setelah dibandingkan dalam penelitian ini dijumpai perbedaan hasil pada metode Sweep dalam penelitian ini menjadi metode yang diusulkan karena memberi hasil yang lebih baik dari rute awal perusahaan. Hal ini dapat dilihat dari hasil perhitungan yang telah dilakukan seperti pada tabel 5 .

Dari tabel di atas kita dapat melihat perubahan rute sesudah menggunakan metode Sweep memiliki hasil yang lebih baik. Kemudian pada tabel 5 kita juga bisa melihat total jarak perjalanan di setiap kunjungan penagihan dimana pada rute awal kunjungan no 1 berjarak 1,7 km kemudian pada rute sebelumnya berjarak $4 \mathrm{~km}$. Dari pengelompokan rute dengan menggunakan metode Sweep memberi hasil total jarak 
semua proses penagihan dan memberi penurunan total jarak sejauh $17,85 \mathrm{~km}$.

Sebagai gambaran bahwa rute perbaikan lebih baik dari rute awal perusahan dapat dilihat pada gambar berikut :

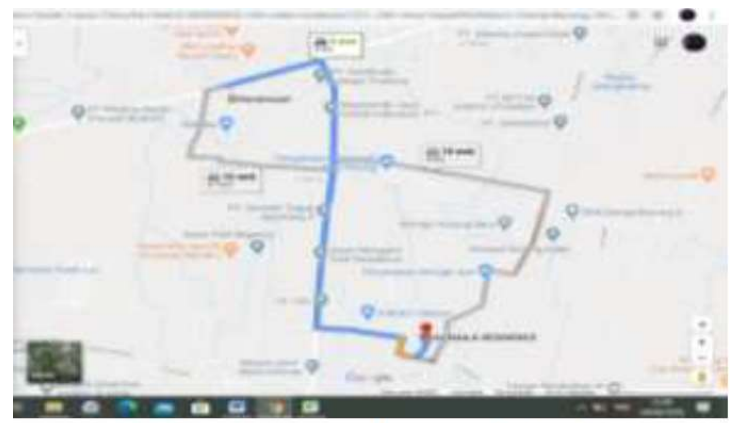

Gambar 6 rute awal sesuai daftar list

Pada gambar 6 dapat dilihat rute no 1 awal kunjungan dimulai dari PERUM DE NAILA BLOK C 9NO 3 DRANCANG MENGANTI GRESIK RT 000RW 000- DS HENDROSARI RT 01 RW 01 KEC MENGANTI KAB GRESIK. Dari rute tersebut jarak yang ditempuh sejauh 4 $\mathrm{Km}$. Sedangkan rute usulan mengunakan metode $\mathrm{Sweep}$ bisa dilihat pada gambar 7 .

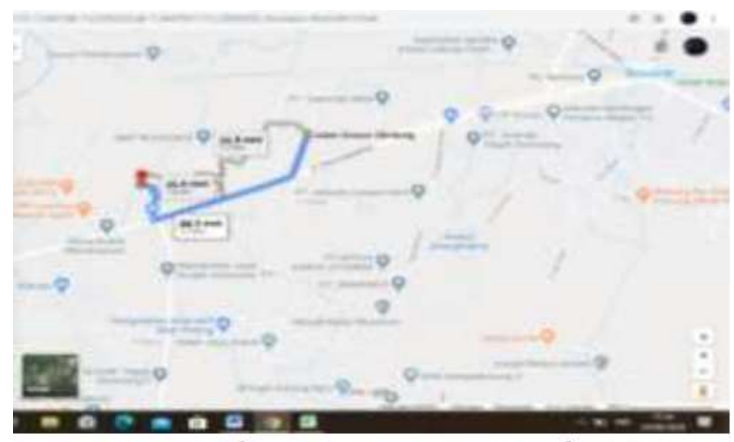

Gambar 7 Rute sesuai metode Sweep

Pada gambar 7 rute no 1 dapat dilihat dari DSN GELINTUNG RT 1 RW 04 DS KEPATIHAN KEC MENGANTI KAB GRESIK - DS KEPATIHAN RT 01 RW 10 KEC MENGANTI KAB GRESIK dari rute tersebut jarak kunjungan mengunakan merode Sweep memberi perbaikan jarak 1,7 km atau 2,3 km lebih dekat dari jarak sebelumnya.

\section{PENUTUP}

Berdasarkan pembahasan mengenai penyelesaian menggunakan Algoritma Sweep pada penentuan rute kunjungan collector, dapat ditarik kesimpulan Algoritma Sweep memberikan solusi pada masalah perbaikan rute kunjungan konsumen bermasalah (kredit macet) di PT. X Cabang Menganti di wilayah Kecamatan Menganti Kabupaten Gresik, Perhitungan Algoritma Sweep pada permasalahan penentuan rute kunjungan collector menghasilkan rute perjalanan, yang ditandai dengan titik A0-A13-A14-A2A15-A5-A6-A3-A5-A1-A4-A12-A11-A10-A8-A7-A9-A0 dibandingkan dari rute sebelumnya sesuai daftar list, ditandai dengan titik A0-A1-A2-A3-A4-A5-A6-A9-A7A8-A10-A11-A12-A13-A14-A15-A0. Dan total jarak tempuh seperti pada tabel 4.5 metode Algoritma Sweep mampu meminimalisir jarak sebesar $39,45 \mathrm{~km}$ dibandingkan rute awal perusahaan pada tabel 4.4 yang mencapai 57,3 km, dan metode Algoritma Sweep mampu menghemat jarak sampai 17,85 km.

\section{DAFTAR PUSTAKA}

Agustina, D. (2016). Integrated vehicle scheduling and routing policies for cross-dock systems [Nanyang Technological University]. https://doi.org/10.32657/10356/68868

Alves, F., Alvelos, F., Rocha, A., Pereira, A., \& Leitão, P. (2019). Periodic Vehicle Routing Problem in a Health Unit. Proceedings of the 8th International Conference on Operations Research and Enterprise Systems, 384-389. https://doi.org/10.5220/000739280384038 9

Anshori, M., \& Fudhla, A. F. (2017, December). Cross Dock Location Analysis and Vehicle Route in Metropolis City Using Weighted Center of Gravity and Clustered Capacitated Sweep Method (study case of Surabaya). The First International Conference on Combinatorics, Graph Theory and Network Topology.

Anshori, Moch., Fudhla, A. F., \& Hidayat, A. (2017). Penentuan Lokasi Fasilitas Crossdock Pada Kota Metropolis Dengan Pendekatan Center Of Gravity. Teknika: Engineering and Sains Journal, 1(2), 83. https://doi.org/10.51804/tesj.v1i2.111.8388

Blocho, M. (2020). Exact algorithms for solving rich vehicle routing problems. In Smart Delivery Systems (pp. 93-99). Elsevier. https://doi.org/10.1016/B978-0-12-8157152.00008-7

Dalmeijer, K., \& Desaulniers, G. (2020). Addressing Orientation Symmetry in the Time Window Assignment Vehicle Routing Problem. INFORMS Journal on Computing, ijoc.2020.0974.

https://doi.org/10.1287/ijoc.2020.0974

Dondo, R., \& Cerdá, J. (2013). A sweep-heuristic based formulation for the vehicle routing problem with cross-docking. Computers \& 
Chemical Engineering, 48, 293-311. https://doi.org/10.1016/j.compchemeng.201 2.09 .016

Fontaine, P., Taube, F., \& Minner, S. (2020). Human solution strategies for the vehicle routing problem: Experimental findings and a choicebased theory. Computers \& Operations Research, 120, 104962. https://doi.org/10.1016/j.cor.2020.104962

Fudhla, A. F., Pujawan, I. N., \& Rahman, A. (2010). Pengembangan Model Matematis untuk Penjadwalan Rute Kendaraan Cross Docking Dalam Rantai Pasok dengan Mempertimbangkan Batasan Kelas Jalan dan Kendaraan Yang Heterogen. Prosiding Seminar Nasional Manajemen Teknologi XI, A6-1 sd A6-8. http://mmt.its.ac.id/download/SEMNAS/SE MNAS XI/MI/06. Prosiding Ahmad Fatih-ok Print.pdf

Gadegaard, S. L., \& Lysgaard, J. (2020). A symmetry-free polynomial formulation of the capacitated vehicle routing problem. Discrete Applied Mathematics. https://doi.org/10.1016/j.dam.2020.02.012

Kouider, T., Cherif-Khettaf, W., \& Oulamara, A. (2019). Large Neighborhood Search for Periodic Electric Vehicle Routing Problem. Proceedings of the 8th International Conference on Operations Research and Enterprise Systems, 169-178. https://doi.org/10.5220/000740920169017 8

Kristanto, T., Muliawati, E. C., Arief, R., \& Hidayat, S. (2018). Pengembangan Sistem Dinamik dalam Pengelolaan Manajemen Distribusi Logistik Terhadap Perkembangan Teknologi Informasi pada PT Sunan Inti Perkasa. Jurnal INFORM, 3(1), 26-31. https://doi.org/10.25139/ojsinf.v3i1.475

Kunnapapdeelert, S., \& Kachitvichyanukul, V. (2018). New enhanced differential evolution algorithms for solving multi-depot vehicle routing problem with multiple pickup and delivery requests. International Journal of Services and Operations Management, 31(3), 370.

https://doi.org/10.1504/IJSOM.2018.095562

Liao, T. W. (2020). Integrated Outbound Vehicle Routing and Scheduling Problem at a MultiDoor Cross-Dock Terminal. IEEE Transactions on Intelligent Transportation Systems, 1-14. https://doi.org/10.1109/TITS.2020.2987986
Liu, C., Hu, D., \& Cai, R. (2019). Research on TwoEchelon Open Location Routing Problem with Simultaneous Pickup and Delivery Base on Perishable Products. CICTP 2019, 4539-4550. https://doi.org/10.1061/9780784482292.39 2

Mańdziuk, J., \& Świechowski, M. (2017). UCT in Capacitated Vehicle Routing Problem with traffic jams. Information Sciences, 406-407, 42-56.

https://doi.org/10.1016/j.ins.2017.04.020

Marinakis, Y. (2015). An improved particle swarm optimization algorithm for the capacitated location routing problem and for the location routing problem with stochastic demands. Applied Soft Computing, 37, 680-701. https://doi.org/10.1016/j.asoc.2015.09.005

PAN, L., \& FU, Z. (2013). Time difference insertion heuristics algorithm for vehicle routing problem with hard time window. Journal of Computer Applications, 32(11), 3042-3043. https://doi.org/10.3724/SP.J.1087.2012.030 42

Schönberger, J. (2015). The Two-Commodity Capacitated Vehicle Routing Problem with Synchronization. IFAC-PapersOnLine, 48(3), 168-173. https://doi.org/10.1016/j.ifacol.2015.06.076

Spliet, R., Dabia, S., \& van Woensel, T. (2018). The Time Window Assignment Vehicle Routing Problem with Time-Dependent Travel Times. Transportation Science, 52(2), 261-276. https://doi.org/10.1287/trsc.2016.0705

Spliet, R., \& Gabor, A. F. (2015). The Time Window Assignment Vehicle Routing Problem. Transportation Science, 49(4), 721-731. https://doi.org/10.1287/trsc.2013.0510

Sundar, K., Venkatachalam, S., \& Rathinam, S. (2016). Formulations and algorithms for the multiple depot, fuel-constrained, multiple vehicle routing problem. 2016 American Control Conference (ACC), 6489-6494. https://doi.org/10.1109/ACC.2016.7526691

Vigo, D. (1996). A heuristic algorithm for the Asymmetric Capacitated Vehicle Routing Problem. European Journal of Operational Research, 89(1-2), 108-126. https://doi.org/10.1016/03772217(96)00223-8

Yang, Q., Hu, D., Chu, H., \& Xu, C. (2018). An Electric Vehicle Routing Problem with Pickup and 
Delivery. CICTP 2018, 176-184. https://doi.org/10.1061/9780784481523.01

7

Zou, H., \& Dessouky, M. M. (2018). A look-ahead partial routing framework for the stochastic and dynamic vehicle routing problem. Journal on Vehicle Routing Algorithms, 1(2-4), 73-88. https://doi.org/10.1007/s41604-018-00065 